\title{
Encouraging Rural Youth Participation in Agriculture: A Case Study of District Sargodha
}

\section{Muhammad Yaseen*, Muhammad Adnan, Muhammad Luqman, Muhammad Zeeshan Majeed and Muhammad Umer Mehmood}

College of Agriculture, University of Sargodha, Sargodha, Pakistan.

\begin{abstract}
Involvement of rural youth in agricultural activities, factors hindering their involvement, and what they think about having a career in the sector have the vigor to provide us with facts about rural youth. Keeping in view the importance of rural youth in agriculture, the present study is designed to find the reasons that hinder rural youth involvement to encourage their participation in agriculture. Based on the facts regarding the population of rural youth, a sample of 450 respondents was selected using a multistage sampling technique. Statistical Package for Social Sciences (SPSS) was used to have descriptive statistics of data. The majority of youth respondents were taking part in agricultural activities like land preparation, sowing practices, irrigation, harvesting and storage obtaining a percentage of $80.2 \%, 77.6 \%, 79.3 \%, 90 \%$, and $75.8 \%$ respectively. Lack of basic farming knowledge and skills is the topmost factor hindering youth involvement in agricultural activities with a mean value of 4.63 and S.D. value of 0.522 . The government should give loans to youth for establishing their agriculture business ranked at $1^{\text {st }}$ with a mean value of 4.72 for youth priorities in agricultural activities. Results of this study would be helpful for public and private sector institutions working for youth engagements to encourage rural youth participation in agricultural activities.

Received | February 07, 2021; Accepted | June 21, 2021; Published | November 06, 2021

*Correspondence | Muhammad Yaseen, University of Sargodha, Sargodha, Pakistan; Email: yaseen99pk@hotmail.com

Citation | Yaseen, M., M. Adnan, M. Luqman, M.Z. Majeed and M.U. Mehmood. 2021. Encouraging rural youth participation in agriculture: A case study of district Sargodha. Journal of Innovative Sciences, 7(2): 244-250.

DOI | https://dx.doi.org/10.17582/journal.jis/2021/7.2.244.250

Keywords | Rural youth, Hindering factors, Youth participation, Youth in agriculture
\end{abstract}

\section{Introduction}

A griculture helps in the provision of different agricultural opportunities to the laborers, growers, and consumers. Different terms could be used for the implementation of larger sustainability in the system of agriculture; productivity is the most important factor (Sulewski and Kloczko-Gajewska, 2014). Another important aspect in this regard is the economy impeding on the sustainability of agriculture. This helps in paying attention to rural youth to the factors, which help in reducing the resources for the system of production. Lastly, it is the duty of all the policymakers, researchers, consumers, and farmers that they should help in achieving the goals of sustainable agriculture. There is a huge need to address this issue at the national, regional, and grass-root levels (Singh et al., 2018).

The main prevailing problem in Pakistan is that the youth of the country is not participating in agricultural activities. The youth is aware of the food insecurities and shortage in the country but they are not motivated to join the field as a profession. The less participation of the youth in agriculture is resulted in lowering the productivity of agriculture. The low productivity and youth participation is dimming the hope of food security and the rise of agriculture in 
the country. The absence of any formal system to organize the enthusiastic youth in Pakistan is one of the main reasons for the low participation of youth in agriculture (ILO, 2017). The disappointing factor is that most of the youth in the country are getting away from the agricultural sector due to their limited scope. More than 55\% of world youth live in rural areas (Ertiaei et al., 2012). They are considered the most disadvantaged groups because they have limited access to educational programs. Most of them could not find a way to get rid of poverty. Maximum youth focus is on getting the education to work in urban areas, there is no education provided for preparing the youth for their future in agriculture (Valrus and Fletcher, 2006).

Cotter et al. (2017) drew that agricultural programs are very helpful for enhancing the knowledge of the community members related to the significance of agriculture because a maximum number of young people prefer to avoid the field of agriculture as their profession. Colombo et al. (2018) have highlighted when youth cannot get the proper education they remain deprived of developing their basic skills for effective employment. FAO (2011) has explicated that the contribution of rural youth is very low in the growth and development of the national economy. Different reasons in this regard are the lack of proper education or indicate an education system. UNESCO's (2004) research results put light on a different kind of reason due to which youth is lacking their interest in agriculture. According to the agriculture needs to be rebranded so that youth could take interest and this field could appeal to them. The study focuses that there should be awareness among the ruler youth in Zimbabwe that they could create wealth from agriculture as well.

Rural youth do not get attracted to agriculture to adopt it as a profession. The main reasons in this regard are the low profit and productivity and a large number of debts on farmers. Rural youth who has adopted agriculture as their profession is due to their family traditions or inheritance. The objectives of the present research are to identify factors hindering the involvement of rural youth in the agriculture sector and to explore various priorities of rural youth concerning their career.

\section{Material and Methods}

Sargodha is located in the Punjab province of Pakistan.
Sargodha district has seven tehsils including Bhalwal, Sahiwal, Kotmomin, Shahpur Sadar, Silanwali, Bhera, and Sargodha (GoP, 2020). The majority of the population in District Sargodha is living in rural areas and they are mostly associated with agriculture as the major source of income (Hayat, 2007). This was the reason that Sargodha district was selected purposively. A descriptive nature survey research design was adopted in the current study.

The population for the present research includes rural youth of age 15-24 years (this age group is defined as a youth by UN; United Nations, 2020). The research covers the rural youth population of district Sargodha. Out of seven tehsils of district Sargodha, four tehsils were selected purposively based on having more union councils (U/C). The four tehsils having more UCs are Sargodha, Bhalwal, Silanwali, and Kotmomin. There are 62 UCs in tehsil Sargodha, out of these UCs 19 have been selected. From tehsil Bhalwal 16 UCs have been selected out of 53. Tehsil Kotmomin has 30 total union councils and 6 have been selected for this study. From the 16 UCs of Silanwali, 04 UCs were selected. Proportionate sampling was adopted in this study, therefore, $30 \%$ of data were collected from each of the two tehsils namely Sargodha and Bhalwal. Similarly, 20\% of data were collected from each of the two tehsils namely Kotmomim and Silanwali. 10 respondents were selected from each UC using the equal distribution technique (Bell et al., 2020). Thus, a total of 450 respondents were finally selected for data collection. Following framework is the clear representation of the sample selection procedure.

In the present research study, an interview schedule was prepared as the main instrument of the study for data collection. The interview schedule was composed of both close and open-ended questions, which were designed to keep in view the objectives of the research study. Five-point Likert-type scales were used in the instrument to record the opinions of the respondents. During data collection, face-to-face interviews of the respondents were organized in rural areas to gather required data from rural youth of particular areas of research. The collected data were coded in Microsoft Excel and then analyzed using Statistical Package for Social Sciences (SPSS). Descriptive statistics were employed for data analysis. In descriptive statistics, frequency, percentage, mean, standard deviation were computed for interpretation of the results. 


\section{Results and Discussion}

This section penlights' the socio-economic characteristics of rural youth, barriers to their involvement in agriculture, and their priorities to consider agriculture as their future career. In a study about youth, age is the factor of ultimate importance. Table 1 explains that the maximum numbers of respondents (above 58\%) are falling in the age ranges of above 20 years. After that $22 \%$ of youth of $19-20$ years age were the participants of the study. It means that the maximum participation of the study was close to the most eligible adults among the rural youth. This period of the age is the decision-making stage about their future career (Luzzo, 1993). This appropriates the stance chosen for this study that either they opt for agriculture as their future career or not.

Table 1: Rural youth distribution according to age.

\begin{tabular}{lll}
\hline Age range (years) & Frequency & Percentage \\
\hline $15-16$ & 33 & 7.3 \\
$17-18$ & 55 & 12.2 \\
$19-20$ & 99 & 22.0 \\
$21-22$ & 131 & 29.1 \\
$23-24$ & 132 & 29.3 \\
Total & 450 & 100.0 \\
\hline
\end{tabular}

Education is a key to make the person confident, creative and helps in maintaining a credible character. Therefore, education level could be stated as the yard for assessing whether having the specified education level lead them to an innovative approach in farming practices or farming as a profession (Siraj, 2006). Table 2 shows that an outsized greater part of the respondents collectively had different levels of education. The data given in Table 2 shows the education of the respondent according to which; $15.3 \%$ completed their graduation, $27.3 \%$ completed intermediate, $28.4 \%$ completed matric and $18.9 \%$ had a middle level of education. However, only $2.7 \%$ of the respondents were illiterate. This states that a bigger portion of rural youth had the education up to and above matriculation.

Landholding deals with the volume and size of the land that could be used by individuals for the production of crops or livestock. The data in Table 3 shows the landholding size of the respondents' families, the results showed that $11.3 \%$ of respondents cultivated up to 2.5 acres of land, $14.0 \%$ had between 2.6 to 5 acres, $24.2 \%$ have between $5.1-7.5$ acres,
$17.8 \%$ use between 7.6-10 acres of land to cultivate, $32.7 \%$ have Above 10 acres of land for cultivation of various crops. These findings justify that majority of rural youth have their association with a reasonable piece of farming land. In this way, their diversion towards sustainable agricultural practices can make a difference.

\begin{tabular}{lll}
$\begin{array}{l}\text { Table 2: Rural youth distribution according to the } \\
\text { education. }\end{array}$ \\
\hline Level of education & Frequency & Percent \\
\hline Illiterate & 12 & 2.7 \\
Primary & 33 & 7.3 \\
Middle & 85 & 18.9 \\
Matric & 128 & 28.4 \\
Intermediate & 123 & 27.3 \\
Graduation & 69 & 15.3 \\
Total & 450 & 100 \\
\hline
\end{tabular}

Table 3: Family landholding size of rural youth.

\begin{tabular}{lll}
\hline Land size & Frequency & Percent \\
\hline Up to 2.5 acres & 51 & 11.3 \\
$2.6-5$ acres & 63 & 14.0 \\
$5.1-7.5$ acres & 109 & 24.2 \\
$7.6-10$ acres & 80 & 17.8 \\
Above 10 acres & 147 & 32.7 \\
Total & 450 & 100.0 \\
\hline
\end{tabular}

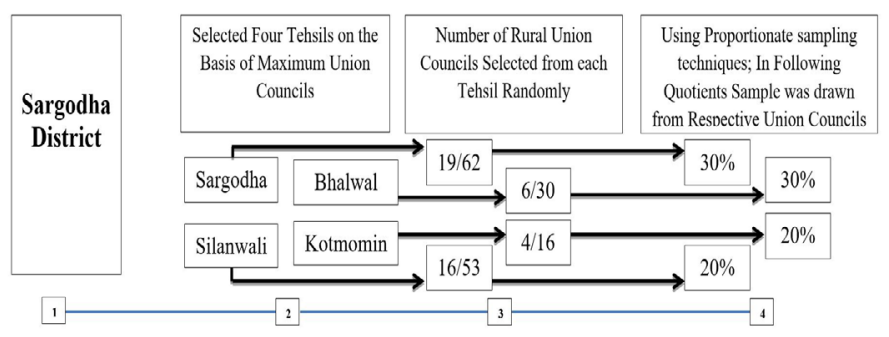

\section{Figure 1: Demonstration of Multistage sampling technique.}

Figures 2 and 3 explain the annual family income of rural youth and the sources of family income of rural youth. Data indicates the annual family income of rural youth showing that more than $70 \%$ of rural youth's families have been earning above 1 million/ year. This ascertains that they may have a stabilized economic situation at the household level. This could be a potential factor in choosing sustainable agricultural practices at their farm level. For obtaining that range of income maximum of the rural youth is already engaged in conventional farming for maximum profit generation and besides that $42 \%$ of 
them are doing jobs alongside farming in addition to their household income.

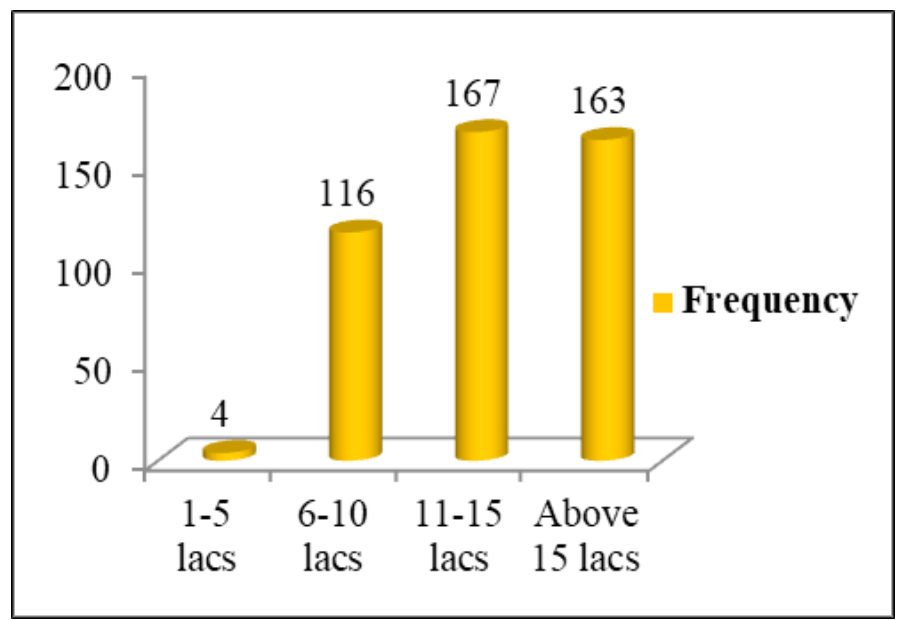

Figure 2: Annual family income of rural youth.

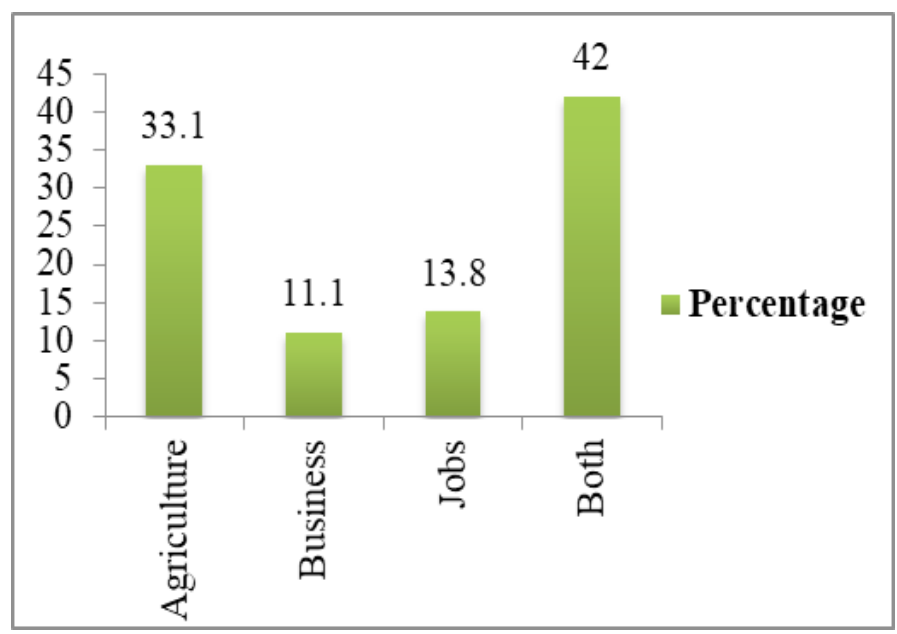

Figure 3: Family income sources of rural youth.

According to Table 4, the type of youth involvement in agricultural activities is of central attention for having a look into their interest and capability they have for utilizing it in sustainable agricultural ways. For this reason, an insight into their involvement in different agricultural activities was necessary. Among the diversified agricultural activities, maximum involvement $(90 \%)$ of rural youth was seen at the "harvesting" stage followed by "land preparation" ( $80 \%)$. A minimum participation of rural youth was recorded in "plant protection measures" ( 70\%) followed by "application of fertilizer" ( 50\%). This scenario has provided us the option for the diversion of rural youth towards sustainable agricultural practices is convenient through reaching them sustainable harvesting and land preparation techniques. Allen et al. (2018) retrieved that rural youth usually involved in the various activities in producing food, from the farm to processing, packaging transporting, storing and selling of agricultural products at a small level and commercial level as well.

Table 4: Rural youth involvement in agricultural activities.

\begin{tabular}{lllll}
\hline Agriculture activities & \multicolumn{3}{c}{ Yes } & \multicolumn{2}{c}{ No } \\
\cline { 2 - 5 } & \%age & F & \%age & F \\
\hline Land preparation & 80.2 & 361 & 19.8 & 89 \\
Sowing practices & 77.6 & 349 & 22.4 & 101 \\
Plant protection measure & 29.6 & 133 & 70.4 & 317 \\
Fertilizer's application & 49.8 & 224 & 50.2 & 226 \\
Irrigation & 79.3 & 357 & 20.7 & 93 \\
Harvesting & 90 & 405 & 10 & 45 \\
Marketing agriculture products & 66.7 & 300 & 33.3 & 150 \\
Storage & 75.8 & 341 & 24.2 & 109 \\
\hline Scale: Yes=1 and No=1 & & & &
\end{tabular}

Table 5 indicates factors restraining rural youth from involving in agriculture as a profession could be considered as a yardstick for the reason of their deflection. Rural youth was "agree" with all the statements of this section. In this way, all of the reasons got the mean value above 4 , as on the Likert scale 4 means the "agree". The highest mean value of 4.63 was obtained by "lack of basic farming knowledge and skills" followed by "lack of continuity of agricultural youth programs" (4.54). The maximum deviation of 0.61 and 0.64 was recorded in the means values of "inadequate infrastructure to support farming activities" and "lack of agricultural equipment and its use" consecutively.

This age period in an individual's life is a decisionmaking period. Youth set the priorities keeping in mind the goals and destination to be reached. Farming is a profession that includes multiple challenges of mind and body therefore young generation expresses little interest in carrying it as their future profession (Vieweger et al., 2014). Among the mentioned priorities in table 6, "government should give loans to youth for the establishment of their agricultural business" obtained the highest mean value of 4.72 . "Addresses of youth issues in agriculture programs" obtained the lowest mean (4.23), even that was above 4=high priority. Zimmerman et al. (2018) argued that young people in rural areas do experience some problems with employment. Consideration of their priorities will enable the extension system to develop a plan which best suited to their interests. This approach will maximize the potential engagement in the directed domain. 
Table 5: Factors hindering rural youth involvement in agriculture.

\begin{tabular}{lll}
\hline Factors hindering & Mean & S.D \\
\hline Communication gap among researcher, youth \& EFS & 4.19 & .47235 \\
Low income from agriculture activities & 4.51 & .55126 \\
Lack of training facilities regarding agriculture & 4.52 & .55092 \\
Lack of basic farming knowledge and skills & 4.63 & .52176 \\
Inadequate infrastructure to support farming activities & 4.42 & .60478 \\
Lack of agricultural equipment and their use & 4.40 & .64363 \\
Lack of knowledge about improved agricultural technology & 4.41 & .55629 \\
Un-inspirational agriculture programs & 4.30 & .52742 \\
Lack of continuity of agriculture youth program & 4.54 & .56177 \\
Inability to establish a link with agriculture agencies & 4.49 & .59786 \\
Absence of desirable job opportunities in the rural areas & 4.52 & .55061 \\
Lack of self-interest and decision making & 4.52 & .55083 \\
Lack of access to the training resources & 4.44 & .58396 \\
High input costs to come up with agriculture sector & 4.39 & .54179 \\
Lack of use sustainable agriculture methods & 4.32 & .52261 \\
The complexity of a sustainable agriculture system & 4.32 & .51118 \\
Lack of knowledge regarding sustainable agricultural practices & 4.32 & .50966 \\
\hline
\end{tabular}

Scale: Strongly disagree $=1$, Disagree $=2$, Neutral $=3$, Agree $=4$ and strongly agree $=5$.

Table 6: Priorities of rural youth concerning their future career.

\begin{tabular}{lll}
\hline Priorities of rural youth & Mean & S.D \\
\hline Skills development training to improve future career & 4.26 & .46857 \\
Independency in decision making & 4.41 & .52010 \\
Developing platforms for collaborative problem-solving discussion & 4.28 & .57938 \\
Addresses of youth issues in agriculture programs & 4.23 & .49846 \\
Establishment of youth platforms in rural areas for opportunities & 4.54 & .51217 \\
Youth agricultural program with a joint venture of relevant stakeholders & 4.28 & .60200 \\
Development of market linkages for building agricultural business for rural youth & 4.42 & .59308 \\
Supportive structural reforms for young entrepreneurs & 4.46 & .53779 \\
Launching ICTs based initiative to harness the potential of youth & 4.41 & .55664 \\
Innovative approaches and programs & 4.40 & .50557 \\
Govt. should help youth(female/male) to start and expand their businesses & 4.54 & .53709 \\
the public and private sector in rural areas targeting rural youth & 4.42 & .53346 \\
Govt. should establish vocational training centers & 4.54 & .53746 \\
Distribution of land on lease to young people for agriculture productivity & 4.67 & .51118 \\
Youth clubs should be established to reduce the gap among youth, research \& industries & 4.56 & .53524 \\
The government should give loans to youth for the establishment of their agricultural business & 4.72 & .47727 \\
Agri graduates should establish rural forums to promote sustainable agricultural practices & 4.51 & .52646 \\
\hline
\end{tabular}

Scale: Low priority $=1$, Moderate priority $=2$, Neutral $=3$, High priority $=4$ and Very high priority $=5$

\section{Conclusion and Recommendations}

The growth of agriculture is not possible without the contribution of rural youth in it. Modern agricultural technologies are getting popularity among the farming community to facilitate farming practices and to improve farm yield and incomes of the farmers. So, the rural youth, being an educated segment of rural societies could play a progressive role in agricultural development. Based on the research findings given below are recommendations for progressive involvement of youth in agriculture: 
- State departments, academia, NGOs and research institutions should launch need-oriented training and capacity building programs for rural youth to improve their role in agricultural development.

- Government should provide loans to rural youth to encourage their participation in agro-based business for the prosperity of the rural economy.

- Government should introduce radical policies for land distributions among the rural youth to improve agricultural productivity.

- Youth clubs/ platforms should be established in rural areas to streamline their participation in agricultural activities.

\section{Novelty Statement}

Promoting rural youth to participate in agricultural activities is a need of time to improve their participation in agricultural development. This will lead to sustainable livelihoods and social prestige for rural youth.

\section{Author's Contribution}

Muhammad Yaseen: Conceived the idea of research, supervised the research and prepared the initial draft. Muhammad Adnan: Data collection from field during survey and reviewed relevant literature.

Muhammad Luqman: Designed research instrument and conducted data analysis, reviewed the draft. Muhammad Zeeshan Majeed: Helped in data analysis and finalized the draft of manuscript.

Muhammad Umer Mehmood: Data collection from field during survey and reviewed relevant literature.

\section{Conflict of interest}

The authors have declared no conflict of interest.

\section{References}

Allen, T., Heinrigs, P., and Heo,I.,2018.Agriculture, food and jobs in West Africa. OECD Library, pp. 16-19. Retrieved from: https://www.oecdilibrary.org/content/paper/dc152bc0-en

Bell, W., Lividini, K. and Masters, W.A., 2020. Global Inequality in Agriculture, Nutrition, and Health. Nutrition, and Health. Retrieved from; https://doi.org/10.2139/ssrn.3638329

Colombo, E., Leonini, L., and Rebughini, P., 2018. A generational attitude: Young adults facing the economic crisis in Milan. Journal of Modern
Italian Studies, 23(1): 61-74. https://doi.org/10 .1080/1354571X.2017.1409532

Cotter, E.W., Teixeira, C., Bontrager, A., Horton, K., and Soriano, D., 2017. Low-income adults' perceptions of farmers' markets and communitysupported agriculture programmes. Public health nutrition, 20(8): 1452-1460. https://doi. org/10.1017/S1368980017000088

Ertiaei, F., Chizari, M., and Jafari, M., 2012. Factors influencing rural youth, participation regarding agricultural development (Case study: Kermanshah Township). Journal of Rural Research, 2(7): 56-75.

Food and Agriculture Organization, 2011. Women in agriculture: Closing the gender gap for development. State of food and agriculture. Rome: Food and Agriculture Organization of the UN (FAO). Retrieved from; https://www. researchgate.net/profile/Anders_Jaegerskog/ publication/262916489 Land deals_a_'green_ revolution'_in_global_food_and_energy_ markets/links/55ed4fa908ae21d099c74ba5/ Land-deals-a-green-revolution-in-globalfood-and-energy-markets.pdf\#page $=25$

Government of Punjab, 2020. District at a Glance. Retrieved from: https://sargodha.punjab.gov. $\mathrm{pk} /$

Hayat, A., 2007. Irrigation sector development in Punjab (Pakistan): Case study of district Sargodha. Retrieved from; https://www. diva-portal.org/smash/get/diva2:16896/ FULLTEXT01.pdf

International Labour Office, 2017. Global Employment Trends for Youth 2017: Paths to a better working future. International Labour Office. Retrieved from; https://www.voced.edu. au/content/ngv:78227

Luzzo, D.A., 1993. Value of career-decisionmaking self-efficacy in predicting careerdecision-making attitudes and skills. Journal of Counseling Psychology, 40(2): 194. https://doi. org/10.1037/0022-0167.40.2.194

Slater, D., and Tacchi, J., 2004. ICT innovations for poverty reduction. Unesco. Retrieved from; https://eprints.qut.edu.au/4398/

Singh, N.P., Anand, B., and Khan, M.A., 2018. Micro-level perception to climate change and adaptation issues: A prelude to mainstreaming climate adaptation into developmental landscape in India. Natural Hazards, 92(3): 1287-1304. https://doi.org/10.1007/s11069- 
018-3250-y

Siraj, S., 2006. Patterns of Family Purchase Behaviour for Selected Products in Rural Context. Aligarh Muslim University.

Sulewski, P., and Kłoczko-Gajewska, A., 2014. Farmers' risk perception, risk aversion and strategies to cope with production risk: An empirical study from Poland. Studies in Agricultural Economics, 116(3): 140-147. https://doi.org/10.7896/j.1414

UNESCO, 2004. National Youth Policy: Ministry of Youth Development, Indigenization and Empowerment. Retrieved from; http://www. unesco.org/

United Nations, 2020. Department of Economic and Social Affairs Youth. Retrieved from: https://www.un.org/development/desa/youth/

Valrus, J. and Fletcher, A., 2006. Guide to social change led by and with young people. The Free Child Project. Retrieved from; http/ en. wikipedia. org. wiki/youth empowerment on, 25(7): 12.

Vieweger, A., Haring, A.M., Padel, S., Doring, T.F., Ekert, S., Lampkin, N. and Otto, K., 2014. The evaluation of the German programme for organic food and farming research: results and pointers for the future. Building Organic Bridges, 2: 351-354.

Zimmerman, M.A., Eisman, A.B., Reischl, T.M., Morrel-Samuels, S., Stoddard, S., Miller, A.L. and Rupp, L., 2018. Youth empoverment solutions: Evaluation of an after-school program to engage middle school students in community change. Health Education and Behavior, 45(1): 20-31. https://doi. org/10.1177/1090198117710491 